\title{
$X$ chromosome variations of Bacillus thuringiensis supernatant resistance and ribosomal DNA content in Drosophila melanogaster wild-type Oregon $\mathbf{R}$ lines
}

\author{
SOLANGE PAUMARD-RIGAL* \& MYRIAM ROSENBERG-BOURGIN \\ Institut Jacques Monod, Université Paris 7, 2 Place Jussieu 75251, Paris Cedex 05, France
}

\begin{abstract}
We have used the supernatant of Bacillus thuringiensis cultures to follow variations of the ribosomal DNA content in a wild-type Oregon $\mathrm{R}$ line of Drosophila melanogaster. These variations are revealed by differences in the degree of resistance to the lethal effect of the supernatant added in the culture medium. Different $\mathrm{X}$ chromosomes, all originated from the same $\mathrm{X}$ chromosome, confer different degrees of resistance. Increases and reductions in the number of the X ribosomal DNA transcriptional units have been found and are correlated with variations in the degree of supernatant resistance. However, no significant variations in X rDNA content were observed between the initial line and this line tested 20 generations later. These results show that the $\mathrm{X}$ rDNA is subjected to frequent modifications that must be essentially complementary and thus originate from reciprocal molecular events. Variations of resistance have been observed in the absence of recombination between homologous chromosomes; this is in agreement with the hypothesis that unequal recombinations between sister chromatids are largely involved in the variations of the $\mathrm{X}$ ribosomal DNA in Oregon R wild-type strains.
\end{abstract}

Keywords: Bacillus thuringiensis, Drosophila melanogaster, beta exotoxin resistance, ribosomal DNA.

\section{Introduction}

The ribosomal DNA, located at the nucleolar organizer sites of the chromosomes, is composed of the genes for the 28S, $18 \mathrm{~S}$ and 5.8S-type RNA, clustered as repeated transcriptional units. In Drosophila melanogaster, the nucleolar organizers are on the heterochromosomes (Cooper, 1959; Ritossa \& Spiegelman, 1965; Spear, 1974). Many ribosomal units of the $\mathrm{X}$ chromosome are interrupted by an insertion into the 28S gene sequence (Long \& Dawid, 1980). Two classes of non-homologous insertions have been identified, named type I, largely represented, and type II (Roiha et al., 1981). Only the uninterrupted units seem to be transcriptionally active (Long \& Dawid, 1979; Long et al., 1980; Kidd \& Glover, 1981; Terracol \& Prud'homme, 1986; Hawley \& Marcus, 1989). The amount of ribosomal DNA on the two chromosomes and the proportion of the different classes of uninterrupted and interrupted units can vary between different strains of $D$. melanogaster and even

*Correspondence. between lines originated from the same strain (Dutton \& Krider, 1984; Endow \& Glover, 1979; RosenbergBourgin et al., 1988a).

Ribosomal DNA evolution in Drosophila has been essentially studied with 'bobbed' mutants because of the possibility of following variations in the amount of functional rDNA by variation of the intensity of the 'bobbed' phenotype, particularly in the case of the magnification phenomenon (Ritossa, 1972; Locker \& Prud'homme, 1973; Tartof, 1973; Terracol \& Prud'homme, 1986; Terracol, 1987). This method needs particular crosses and genotypes with a very low level of active ribosomal units (Tartof, 1974; Hawley \& Tartof, 1985; Marcus et al. 1986) and cannot be used to follow variations in the rDNA amount in wild-type flies.

We have developed a method based on the resistance to Bacillus thuringiensis supernatant that reveals modifications in the rDNA content of wild-type strains (Rosenberg-Bourgin et al., 1988b; Paumard-Rigal \& Rosenberg-Bourgin, 1993). The supernatant of cultures of $B$. thuringiensis Berliner strain contains a thermostable toxin (McConnel \& Richards, 1959), the 
beta exotoxin or thuringiensin, that acts in vivo as a preferential inhibitor of the nucleolar RNA polymerase (Mackedonski et al., 1972; Beebee \& Bond, 1973). We have previously shown that the supernatant, like the purified toxin, has a lethal effect during the development stage when added to the nutritional medium of Drosophila; this lethal effect increases when the number of active ribosomal DNA units decreases (Paumard \& Bourgin-Rosenberg, 1981; RosenbergBourgin et al., 1988b; Paumard-Rigal \& RosenbergBourgin, 1992).

We have shown (Paumard-Rigal \& RosenbergBourgin, 1992) that the addition of B. thuringiensis supernatant to $D$. melanogaster culture medium makes possible the detection of modifications in $\mathrm{X}$ ribosomal DNA content between two wild-type Oregon $\mathrm{R}$ lines, one isolated from a variant Oregon $\mathrm{R}$ population selected at high temperature and the other isolated from the original population (Paumard-Rigal \& Rosenberg-Bourgin, 1990). The variations observed between the two lines have led us to hypothesize that modifications in the $\mathrm{X}$ rDNA content are not rare events.

Here we use B. thuringiensis supernatant to follow variations of the ribosomal DNA content of one Oregon $\mathrm{R}$ wild-type line $\mathrm{X}$ chromosome to determine how the modifications arise in the X rDNA.

\section{Materials and methods}

\section{D. melanogaster stocks}

All the Drosophila strains came from the stock of the Centre de Génétique Moléculaire of Gif sur Yvette (France).

The 1C line came from the Oregon $\mathrm{R}$ stock (Paumard-Rigal \& Rosenberg-Bourgin, 1990).

The '94' strain has C1(RM) females with two attached X chromosomes (Lindsley \& Grell, 1968).

The Müller 5 strain is $\left(\operatorname{In}(1) \mathrm{sc}^{\mathrm{SIL}} \mathrm{sc}^{8 \mathrm{R}}+\mathrm{S}, \mathrm{sc}^{\mathrm{S} 1} \mathrm{sc}^{8} \mathrm{w}^{\mathrm{a}}\right.$ $\mathrm{B})$. This double inversion on the $\mathrm{X}$ chromosome includes the nucleolar organizer and makes the recovery of recombinants from $\mathrm{X}+/ \mathrm{X} \mathrm{Mu_{5 }}$ females very unlikely.

Drosophila stocks were grown on cornmeal yeast extract agar medium ( $75 \mathrm{~g}$ cornmeal, 75 g yeast extract, $12.5 \mathrm{~g}$ agar-agar and $45 \mathrm{ml}$ of a $10 \mathrm{~g} / 100 \mathrm{ml}$ solution of methyl-para-hydroxy-benzoate in 90 per cent alcohol for 1 litre of medium).

\section{Evaluation of the effect of $\mathrm{B}$. thuringiensis thermostable supernatant}

Drosophila were grown at $25^{\circ} \mathrm{C}$. Supernatant from a culture of $B$. thuringiensis Berliner strain harvested at the end of sporulation was autoclaved for $20 \mathrm{~min}$ at $120^{\circ} \mathrm{C}$ and added to the standard medium at a final concentration of 1 per cent and 1.5 per cent $(\mathrm{v} / \mathrm{v}) . B$. thuringiensis cultures were grown at $30^{\circ} \mathrm{C}$ under the conditions described in Lecadet \& Dedonder (1971). The supernatant effect was assayed by counting the adults emerging after all their development had taken place in a supplemented supernatant medium, from eggs laid on this medium over 4 days by 12 females mated with 12 males. The same batch of bacterial culture supernatant was used for all experiments.

\section{Construction of the lines}

From the 1C line previously described (Paumard-Rigal \& Rosenberg-Bourgin, 1992), several lines, each isolated from one single $\mathrm{X}$ chromosome, were constructed by successive crosses involving the Müller $5 \mathrm{X}$ chromosome introduced in the $1 \mathrm{C}$ autosomal context ((Müller 5)1C strain).

The $1 C_{11}$ line, which gives the same results in $B$. thuringiensis-supplemented supernatant medium as the initial $1 \mathrm{C}$ line, was selected for the construction of further lines.

At 20 generations later, new lines, each isolated from one single $\mathrm{X}$ chromosome of the $1 \mathrm{C}_{11}$ line, were constructed using the same method.

\section{Study of variations of supernatant resistance in the absence of recombination between homologous $X$ chromosomes}

From four of the new lines mentioned above, one male chosen at random from each population was crossed with (Müller 5) $1 \mathrm{C}$ females and then one $\mathrm{F}_{1}$ female was crossed with (Müller 5)1C males. The $(\mathrm{B}+)$ male descendants were individually crossed with ten females of the 94 strain on supplemented supernatant medium.

\section{Extraction of brain DNA from third-instar larvae}

Brains and imaginal dises of about 30 third-instar female larvae were dissected in Drosophila Ringer solution (Ephrussi \& Beadle, 1936). After addition of $7 \mu \mathrm{l}$ of a $2 \mathrm{mg} / \mu \mathrm{l}$ solution of self-digested pronase, they were incubated for 22-24 h at room temperature with slow agitation in Eppendorf tubes in $250 \mu \mathrm{l}$ of $50 \mathrm{~mm}$ Tris $\mathrm{HCl} p \mathrm{H} \mathrm{7.8,} 100 \mathrm{~mm}$ EDTA and 0.5 per cent SDS. After incubation, $250 \mu \mathrm{l} \mathrm{NaCl} 2 \mathrm{M}$ and $500 \mu \mathrm{l}$ of chloroform-isoamyl alcohol (24:1) were added successively. The preparation was gently mixed for 3 min, kept for $10 \mathrm{~min}$ at $0^{\circ} \mathrm{C}$ and then centrifuged for 5 min at $12000 \mathrm{~g}$. Then $2 \mu \mathrm{l}$ of $10 \mathrm{mg} \mathrm{ml}^{-1}$ RNAse A was added to this supernatant and incubated for $2 \mathrm{~h}$ at $37^{\circ} \mathrm{C}$. After a second treatment with chloroform- 
isoamyl alcohol, the DNA was precipitated for $15 \mathrm{~min}$ at $-70^{\circ} \mathrm{C}$ by addition of $1 \mathrm{ml}$ ethanol and was dissolved in $30 \mu \mathrm{l} \mathrm{TE} \mathrm{(10} \mathrm{mM} \mathrm{Tris} \mathrm{HCl} p \mathrm{H} \mathrm{8,1} \mathrm{mm} \mathrm{EDTA)} \mathrm{after}$ centrifugation and drying.

\section{The $p D m r Y_{12}$ plasmid}

The pDmr $\mathrm{Y}_{12}$ plasmid, isolated by the method of Birnboim \& Doly (1979), contains an $11.7 \mathrm{~kb}$ EcoRI ins- ribosomal Dmr $\mathrm{Y}_{12}$ fragment in the EcoRI site of ColEI(Wellauer et al., 1978).

\section{DNA electrophoresis, transfer and hybridization}

Electrophoresis was performed in $p \mathrm{H} 8$ borate buffer ( $89 \mathrm{~mm}$ Tris base, $89 \mathrm{~mm}$ boric acid, 2 mM EDTA $p \mathrm{H} 8$ ) with addition of $1 \mu \mathrm{g} \mathrm{ml}^{-1}$ of ethidium bromide. After electrophoresis, the agarose gels were treated successively twice for $15 \mathrm{~min}$ with $0.25 \mathrm{M} \mathrm{HCl}$, twice for 15 min with $0.5 \mathrm{M} \mathrm{NaOH}, 1.5 \mathrm{M} \mathrm{NaCl}$, and twice for 30 min with $0.02 \mathrm{M} \mathrm{NaOH}, 1 \mathrm{M}$ ammonium acetate. Transfer to Schleicher et Schüll BA 85 nitrocellulose filter was carried out in $0.02 \mathrm{M} \mathrm{NaOH}, 1 \mathrm{M}$ ammonium acetate for 10-12 h. DNA was fixed to the membrane by heating for $2 \mathrm{~h}$ at $80^{\circ} \mathrm{C}$. Filters were prehybridized at $42^{\circ} \mathrm{C}$ for $2 \mathrm{~h}$ in the following mixture (Wahl et al. 1979): 50 per cent formamide, $5 \times$ SSC $(1 \times$ SSC is $150 \mathrm{~mm} \mathrm{NaCl}, 15 \mathrm{~mm}$ sodium citrate), $5 \times$ Denhardt solution $(1 \times$ Denhardt is 0.02 per cent polyvinylpyrrolidone, 0.02 per cent Ficoll, 0.02 per cent bovine serum albumin), $50 \mathrm{~mm}$ sodium phosphate buffer $(\mathrm{pH}$ 7.4), 1 per cent SDS. The filters were then hybridized at $42^{\circ} \mathrm{C}$ for $20-24 \mathrm{~h}$ in 50 per cent formamide, $5 \times$ SSC, $1 \times$ Denhardt solution, $20 \mathrm{~mm}$ sodium phosphate buffer ( $p H$ 7.4), 6 per cent dextransulphate 500, 1 per cent SDS, $100 \mu \mathrm{g} \mathrm{ml}^{-1}$ of yeast tRNA, $2 \mathrm{ng} \mathrm{ml}^{-1}{ }^{32} \mathrm{P}$ nicktranslated $\mathrm{pDmrY}_{12}$ or $\mathrm{DmrY}_{12}\left(0.5-1.10^{8}\right.$ c.p.m./ $\mu \mathrm{g})$ denatured for $10 \mathrm{~min}$ at $100^{\circ} \mathrm{C}$. The filters were rinsed successively, once at room temperature for 5 $\min$ in $2 \mathrm{X} \mathrm{SSC}$, three times at $42^{\circ} \mathrm{C}$ for $20 \mathrm{~min}$ in $2 \times \mathrm{SSC}-1$ per cent SDS, twice at $42^{\circ} \mathrm{C}$ for $20 \mathrm{~min}$ in $0.5 \times$ SSC -0.1 per cent SDS. Filters were exposed to Kodak X-Omat $\mathrm{R}$ films for different times (in general 1-72 h). Autoradiographs were scanned on a Shimadzu CS 930 densitometer. The areas were determined with several autoradiographs within the linear response range of the film.

\section{Ribosomal DNA quantification}

The number of ribosomal units per $\mathrm{X}$ chromosome was determined after loading Drosophila DNA samples on a 1 per cent agarose minigel containing ethidium bromide. The quantity of total Drosophila
DNA in each slot was first evaluated: known quantities of lambda DNA were loaded on the same minigel and, after a short migration, the fluorescence intensity under U.V. light of the different samples of Drosophila DNA was compared with that of the standards. Fluorescence intensity of each sample was determined precisely after scanning the photographic negatives. The number of haploid genomes (that is the same as the number of $\mathrm{X}$ chromosomes in the females), was calculated knowing that the haploid genome contains $0.18 \mathrm{pg}$ DNA.

The number of ribosomal units in each Drosophila DNA sample was determined by loading known quantities of $\mathrm{pDmr} \mathrm{Y}_{12}$ with $250 \mathrm{ng}$ of calf thymus DNA in the slots where the lambda DNA had first been loaded. After a short electrophoresis, the DNA was transferred to nitrocellulose filters and hybridized with ${ }^{32} \mathrm{P}$ $\mathrm{DmrY}_{12}$. The hybridization signals of the various Drosophila DNA samples were compared with those of the standards.

The intensity of the signal was precisely determined by scanning the autoradiographs. The determination of the number of ribosomal units was realized by considering the Drosophila insert DmrY ${ }_{12}$ (representing 67 per cent of the total $\mathrm{pDmr} \mathrm{Y}_{12}$ plasmid and corresponding to a $11.7 \mathrm{~kb}$ uninterrupted unit) as equivalent to $1.52 \times 10^{-5} \mathrm{pg}$ of DNA. The method is illustrated in Rosenberg-Bourgin et al. (1988a).

The ratio between the number of ribosomal units and the number of haploid genomes, calculated for at least three independent DNA samples, allows the determination of the number of ribosomal units per $\mathrm{X}$ chromosome.

\section{Results}

\section{$X$ chromosome variations in supernatant resistance and in rDNA content between lines each isolated from one single $X$ chromosome of the $1 C_{11}$ line}

The results obtained in the presence of 1 per cent $B$. thuringiensis supernatant with the $1 C_{11}$ line isolated from the 1C Oregon $\mathrm{R}$ line (Paumard-Rigal and Rosenberg-Bourgin, 1990) and with 29 lines each isolated from one single $\mathrm{X}$ chromosome of this line, 20 generations after its establishment, are reported in Table 1.

The sex ratio is a measure of the supernatant resistance conferred by the $\mathrm{X}$ chromosomes of the different lines. Significant variations are observed between the lines; the sex ratio values are distributed on both sides of the $1 C_{11}$ value $(0.43-1.03)$. For 11 lines, the $\mathrm{X} / 0$ males are significantly less resistant than those of the $1 \mathrm{C}_{11}$ line; for six lines, they are significantly more resistant. 
Table 1 Resistance to 1 per cent $B$. thuringiensis supernatant of the X/0 males obtained from crosses between X.X 94 females and males of the $1 C_{11}$ line or of the different lines derived from this line

\begin{tabular}{rlcllllll}
\hline $\begin{array}{l}\text { Line } \\
\text { number }\end{array}$ & $\begin{array}{l}\text { Males/females } \\
\text { X/0/X.X/Y }\end{array}$ & Ratio & $\begin{array}{l}\text { Line } \\
\text { number }\end{array}$ & $\begin{array}{l}\text { Males/females } \\
\text { X/0/X.X/Y }\end{array}$ & Ratio & $\begin{array}{l}\text { Line } \\
\text { number }\end{array}$ & $\begin{array}{l}\text { Males/females } \\
\text { X/0/X.X/Y }\end{array}$ & Ratio \\
\hline 9 & $78 / 183$ & 0.43 & 26 & $91 / 143$ & 0.64 & 28 & $125 / 157$ & 0.80 \\
18 & $79 / 179$ & 0.44 & 12 & $110 / 168$ & 0.65 & 32 & $121 / 149$ & 0.81 \\
10 & $80 / 165$ & 0.48 & 24 & $107 / 165$ & 0.65 & 27 & $151 / 178$ & 0.85 \\
23 & $87 / 170$ & 0.51 & 14 & $145 / 159$ & 0.66 & 8 & $155 / 181$ & 0.86 \\
2 & $64 / 130$ & 0.53 & 5 & $117 / 174$ & 0.67 & 31 & $140 / 158$ & 0.89 \\
6 & $85 / 156$ & 0.54 & 4 & $101 / 150$ & 0.68 & 21 & $145 / 141$ & 1.03 \\
11 & $90 / 161$ & 0.55 & $1 C_{11}$ & $111 / 163$ & 0.68 & & & \\
15 & $87 / 154$ & 0.56 & 34 & $68 / 98$ & 0.69 & & & \\
7 & $97 / 171$ & 0.57 & 20 & $119 / 168$ & 0.70 & & & \\
13 & $116 / 200$ & 0.58 & 17 & $135 / 189$ & 0.71 & & & \\
22 & $108 / 186$ & 0.58 & 1 & $140 / 185$ & 0.75 & & & \\
& & & 30 & $115 / 153$ & 0.75 & & & \\
\end{tabular}

Male and female values are means of five flasks.

Table 2 Number of $\mathrm{X}$ ribosomal units of the different lines derived from the $\mathrm{IC}_{11}$ line

\begin{tabular}{|c|c|c|c|}
\hline Line number & $\begin{array}{l}\text { Number of X } \\
\text { ribosomal units }\end{array}$ & S.E.M. & $\begin{array}{l}\text { Difference with } \\
\text { initial } 1 C_{11} \text { line }\end{array}$ \\
\hline $\begin{array}{l}\text { Initial } 1 C_{11} \text { line } \\
\quad \text { (DNA sampled at origin) }\end{array}$ & 194 & 11 & \\
\hline $\begin{array}{c}1 \mathrm{C}_{1 !} \text { line (DNA sampled } \\
20 \text { generations later) }\end{array}$ & 201 & 10 & +7 \\
\hline 21 & 245 & 10 & +44 \\
\hline 31 & 248 & 10 & +47 \\
\hline 32 & 235 & 6 & +34 \\
\hline 6 & 166 & 7 & -35 \\
\hline 18 & 158 & 7 & -43 \\
\hline 9 & 156 & 8 & -45 \\
\hline
\end{tabular}

S.E.M. $=$ standard error of the mean (three independent DNA samples for each line).

Six lines (numbered 9, 18, 31, 21, 6 and 32) were chosen for further biochemical studies. Lines 9 and 18 on one hand, lines 31 and 21 on the other, were selected because they present the most extreme variations of $\mathrm{X} / 0$ male resistance in a supernatant-supplemented medium compared with the $1 \mathrm{C}_{11}$ line. The two other lines were chosen at random from lines with an intermediate $\mathrm{X} / 0$ male resistance (lower resistance for line 6 , higher resistance for line 32 ).

The amount of X ribosomal DNA in each of these lines and in the $1 \mathrm{C}_{11}$ line is reported in Table 2.
There is only a small variation between the number of $\mathrm{X}$ ribosomal DNA units in the $1 \mathrm{C}_{11}$ line at origin and the number of $\mathrm{X}$ ribosomal DNA units of this line 20 generations later (DNA sampled at the same time as the other lines): 194 and 201, respectively.

On the contrary, the number of $\mathrm{X}$ ribosomal units varies between the $1 \mathrm{C}_{11}$ line and the different lines as well as between the different lines themselves (from 156 to 245 ).

The variations are in agreement with the results obtained with the $B$. thuringiensis supernatant. The 
Table 3 Resistance to 1.5 per cent $B$. thuringiensis supernatant of the $\mathrm{X} / 0$ males obtained from each individual cross between 94 females and the $20(\mathrm{~B}+)$ males issued from one single $\mathrm{X}_{1 \mathrm{C}_{11 \mathrm{n}}} / \mathrm{X} \mathrm{Mu}_{5}$ female for the lines $18,6,32$ and 21
(a) line 18
(b) line 6

\begin{tabular}{lllc}
\hline $\mathrm{X} / 0$ males$/ \mathrm{X} . \mathrm{X} / \mathrm{Y}$ females & & \multicolumn{2}{l}{$\mathrm{X} / 0 \mathrm{males} / \mathrm{X} . \mathrm{X} / \mathrm{Y}$ females } \\
\hline $34 / 112=0.28$ & $55 / 133=0.41$ & $40 / 129=0.31$ & $72 / 139=0.52$ \\
$43 / 139=0.31$ & $71 / 168=0.42$ & $31 / 95=0.33$ & $77 / 137=0.56$ \\
$42 / 134=0.31$ & $64 / 151=0.42$ & $45 / 126=0.36$ & $59 / 100=0.59$ \\
$49 / 145=0.34$ & $56 / 131=0.43$ & $50 / 129=0.39$ & $104 / 177=0.59$ \\
$44 / 124=0.35$ & $64 / 146=0.44$ & $53 / 131=0.40$ & $57 / 94=0.61$ \\
$40 / 170=0.37$ & $58 / 124=0.47$ & $77 / 191=0.40$ & $72 / 117=0.61$ \\
$47 / 122=0.38$ & $42 / 104=0.50$ & $68 / 169=0.40$ & $69 / 110=0.63$ \\
$51 / 127=0.40$ & $87 / 162=0.54$ & $63 / 157=0.40$ & $73 / 116=0.63$ \\
$80 / 198=0.40$ & $57 / 104=0.55$ & $53 / 128=0.41$ & $59 / 89=0.66$ \\
$46 / 112=0.41$ & $112 / 131=0.85$ & $69 / 162=0.42$ & $81 / 116=0.70$ \\
& & $50 / 116=0.43$ & $99 / 138=0.72$ \\
& & $38 / 84=0.45$ & $69 / 96=0.72$ \\
& & $81 / 173=0.47$ & $100 / 138=0.73$ \\
& & $72 / 148=0.49$ & $93 / 125=0.74$ \\
& & $83 / 167=0.50$ & $86 / 113=0.76$ \\
& & $40 / 77=0.52$ & $82 / 91=0.90$
\end{tabular}

(c) line 32

(d) line 21

\begin{tabular}{lccc}
\hline $\mathrm{X} / 0$ males $/ \mathrm{X} . \mathrm{X} / \mathrm{Y}$ females & \multicolumn{3}{l}{$\mathrm{X} / 0$ males $\mathrm{X} . \mathrm{X} / \mathrm{Y}$ females } \\
\hline $32 / 122=0.26$ & $106 / 152=0.70$ & $41 / 103=0.40$ & $65 / 89=0.70$ \\
$53 / 101=0.52$ & $96 / 133=0.72$ & $49 / 112=0.44$ & $66 / 89=0.74$ \\
$70 / 131=0.53$ & $77 / 105=0.73$ & $98 / 210=0.47$ & $81 / 107=0.76$ \\
$65 / 118=0.55$ & $83 / 111=0.75$ & $69 / 143=0.48$ & $105 / 134=0.78$ \\
$74 / 121=0.61$ & $89 / 116=0.78$ & $56 / 114=0.49$ & $105 / 127=0.83$ \\
$72 / 117=0.61$ & $79 / 101=0.78$ & $55 / 96=0.57$ & $122 / 147=0.83$ \\
$57 / 89=0.64$ & $67 / 82=0.82$ & $86 / 144=0.60$ & $77 / 92=0.84$ \\
$97 / 135=0.64$ & $109 / 130=0.84$ & $96 / 158=0.61$ & $112 / 134=0.84$ \\
$64 / 98=0.65$ & $151 / 150=1.0$ & $71 / 114=0.62$ & $75 / 88=0.85$ \\
$80 / 120=0.67$ & $105 / 103=1.02$ & $80 / 129=0.62$ & $132 / 146=0.90$ \\
& & $70 / 106=0.66$ & $118 / 128=0.92$ \\
& & $101 / 153=0.66$ & $150 / 161=0.93$ \\
& & $67 / 101=0.67$ & $137 / 139=0.98$ \\
& & $93 / 138=0.67$ & $92 / 90=1.03$ \\
& & $65 / 92=0.70$ & $141 / 137=1.03$ \\
& & $87 / 122=0.71$ & $127 / 116=1.09$ \\
& & $128 / 168=0.73$ & $130 / 114=1.14$ \\
\hline
\end{tabular}

lines presenting a higher $X$ resistance than the $X 1 C_{11}$ (i.e. 21,31 and 32 ) have a higher number of $X$ ribosomal units. Conversely, the lines with lower $\mathrm{X}$ resistance (i.e. 9, 18 and 6) have a lower number of $\mathrm{X}$ ribosomal units.

It can be pointed out that the difference between the number of $\mathrm{X}$ ribosomal units of the two intermediate lines ( 32 and 6 ) and the number of X ribosomal units of the $1 \mathrm{C}_{11}$ line is about 18 per cent, while this difference is more than 22 per cent for the most extreme lines.

\section{Variations of supernatant resistance in the absence of recombination between homologous $X$ chromosomes for lines 18, 6, 32 and 21}

The results obtained with 1.5 per cent $B$. thuringiensis supernatant in crosses between $94 \mathrm{C} 1(\mathrm{RM})$ females and each of the $(\mathrm{B}+)$ males generated by one single $\mathrm{X}_{1 \mathrm{C}_{11 \mathrm{n}}} / \mathrm{X} \mathrm{Mu}_{5}$ female are reported in Table 3 (a: line 18, b: line 6, c: line 32, d: line 21). Significant variations in male/female ratios can be observed for each of the 
four lines. They reveal variations in the degree of supernatant resistance conferred by different $\mathrm{X}$ chromosomes obtained from one single $\mathrm{X} 1 \mathrm{C}_{11 \mathrm{n}} / \mathrm{X} \mathrm{Mu}_{5}$ female.

The average male/female ratios calculated from the values presented in the four tables (respectively 0.43 for line $18,0.53$ for line $6,0.69$ for line 32 and 0.74 for line 21) are statistically different. Comparison of these ratios leads to the same classification of the four lines as previously reported in Table 1 .

\section{Discussion}

We have shown that different $\mathrm{X}$ chromosomes, all originated from the $1 \mathrm{C}_{11}$ line which has been constructed from one single $\mathrm{X}$ chromosome, confer different degrees of resistance to the lethal effect of $B$. thuringiensis supernatant. Compared with the resistance conferred by $\mathrm{X}$ chromosomes of the ${ }^{1} \mathrm{C}_{11}$ line, both an increase and a reduction in the degree of resistance was observed. For the six lines studied at a molecular level, we have observed a variation in the $\mathrm{X}$ rDNA content, compared with the $1 \mathrm{C}_{11}$ line and, for each line, a correlation between the variation in the degree of resistance and the variation at the $\mathrm{X}$ nucleolar organizer locus. No significant variations in $\mathrm{X}$ rDNA content have been observed between the initial $1 \mathrm{C}_{11}$ line and this line tested 20 generations later.

In a previous paper (Paumard-Rigal \& RosenbergBourgin, 1992), we had suggested that the modifications at the X rDNA locus were essentially reciprocal modifications. This hypothesis is corroborated by the results obtained here: we have observed, between the six lines studied at a molecular level, variations of $\mathrm{X}$ rDNA content in both directions while no variation in the $\mathrm{X}$ rDNA content of the $1 \mathrm{C}_{11}$ population from which the lines were isolated has been found. The $\mathrm{X}$ rDNA is thus subjected to frequent modifications that must be essentially complementary and thus originate from reciprocal molecular events.

The variations of resistance observed between the different $\mathrm{X}$ chromosomes obtained from single $\mathrm{X}$ $1 \mathrm{C}_{11} / \mathrm{X} \mathrm{Mu}_{5}$ females reveal variations of the $\mathrm{X}$ rDNA content in the absence of recombination between homologous chromosomes. Only unequal recombinations between sister chromatids can explain such results.

Unequal recombinations between sister chromatids had been considered by several authors as being the mechanism involved in the reversion of the 'bobbed' mutations during the magnification process (Tartof, 1973, 1974; Endow et al., 1984; Hawley \& Tartof, 1985).

Our results are in agreement with the hypothesis that these recombinations are extensively involved in the variations of the $\mathrm{X}$ ribosomal DNA in wild-type strains.

\section{References}

BEEBEE, T. J. C. AND BOND, R. P. M. 1973. Effect of the exotoxin of Bacillus thuringiensis on normal and ecdysone stimulated ribonucleic acid polymerase activity in intact nuclei from the fat-body of Sarcophaga bullata larvae. Biochem. J., $136,1-7$.

BIRNBOIM, H. C. AND DOLY, J. 1979. A rapid alkaline extraction procedure for screening recombinant plasmid DNA. $\mathrm{Nucl}$. Acid. Res., 7, 1513-1523.

COOPER, K. W. 1959. Cytogenetic analysis of major heterochromatic elements (especially $\mathrm{Xh}$ and $\mathrm{Y}$ ) in Drosophila melanogaster and the theory of 'heterochromatin'. Chromosoma, 10, 535-588.

DUTTON, F. L. AND KRIDER, M. M. 1984. Ribosomal RNA cistrons of $\mathrm{X}$ chromosomes clonally derived from $D$. melanogaster laboratory populations:redundancy, organization and stability. Genetics, 107, 405-421.

ENDOW, S. A. AND GLOVER, D. M. 1979. Differential replication of ribosomal repeats in polytene nuclei of Drosophila. Cell, 17, 597-605.

ENDOW, S. A., KOMMA, D. J. AND ATwOOD, K, C. 1984. Ring chromosomes and rDNA magnification in Drosophila. Genetics, 108, 969-983.

EPHRUSSI, B. AND BEADLE, G. V. 1936. A technique of transplantation for Drosophila. Am. Nature, 70, 218-225.

HAWLEY, R. S. AND MARCUS, C. H. 1989. Recombinational controls of rDNA redundancy in Drosophila. Ann. Rev. Genet., 23, 87-120.

HAWLEY, R. S. AND TARTOF, K. D. 1985. A two-stage model for the control of rDNA magnification. Genetics, 109, $691-700$.

KIDD, S. J. AND GLOVER, D. M. 1981. Drosophila melanogaster ribosomal DNA containing type 11 insertions is variably transcribed in different strains and tissues. $J$. Mol. Biol., 151, 645-662.

LECADET, M. M. AND DEDONDER, R. 1971. Biogenesis of the crystalline inclusion of Bacillus thuringiensis during sporulation. Eur. J. Biochem., 23, 282-294.

LINDSLEY, D. L. AND GRELL, E. H. 1968. Genetic variations of Drosophila melanogaster. Carnegie Institution of Washington Publication 627.

LOCKER, D. AND PRUD'HOMme, N. 1973. Etude de plusieurs facteurs faisant varier la fréquence de réversion au locus bobbed chez Drosophila melanogaster. Mol. Gen. Genet., 124,1119

LONG, E. O. AND DAWID, 1. B. 1979. Expression of ribosomal DNA insertions in Drosophila melanogaster. Cell, 18, 1185-1196.

LONG, E. O. AND DAWID, 1. B. 1980. Repeated genes in Eucaryotes. Ann. Rev. Biochem., 49, 727-764.

LONG, E. O., REBBERT, M. L. AND DAWID, I. B. 1980. Structure and expression of ribosomal RNA genes of Drosophila melanogaster interrupted by type 2 insertions. Cold Spring Harbor Symp. Quant. Biol., 45, 667-672.

MCCONNEL, E. AND RICHARDS, A. G. 1959. The production by 
Bacillus thuringiensis Berliner of a heat-stable substance toxic for insects. Can. J. Microbiol., 5, 161-168.

MACKEDONSKI, v. V., HADIOLOV, A. A. AND SEBESTA, K. 1972. Preferential in vivo inhibition of ribosomal ribonucleic acid synthetic in mouse liver by exotoxin of Bacillus thuringiensis. FEBS Lett., 21, 2:211-214.

MARCUS, C. H., ZITRON, A. E., WRIGHT, D. A. AND HAWLEY, R. S. 1986. Autosomal modifiers of the bobbed phenotype are a major component of the rDNA magnification paradox in Drosophila melanogaster. Genetics, 113, 305-319.

PAUMARD, S. AND BOURGIN-ROSENBERG, M. 1981. Utilisation du surnageant de cultures de Bacillus thuringiensis dans une étude in vivo du fonctionnement de l'organisateur nucléolaire chez Drosophila melanogaster. C.R. Acad. Sci. Paris, 293, 257-260.

PAUMARD-RIGAL, S. AND ROSENBERG-BOURGIN, M. 1990. High temperature of development and selection of Bacillus thuringiensis supernatant resistant females in a Drosophila melanogaster Oregon R strain. Genetica, 81, 215-228.

PAUMARD-RIGAL, S. AND ROSENBERG-BOURGIN, M. 1992. Increase of the resistance to the Bacillus thuringiensis supernatant effect in a Drosophila melanogaster wild-type Oregon R line. Heredity, 69, 539-546.

RIrossA, F. M. 1972. Procedure for magnification of lethal deletions of genes for ribosomal RNA. Nature New Biol., 240, 109-111.

RITOSSA, F. M. AND SPIEGELMAN, S. 1965. Localization of DNA complementary to ribosomal RNA in the nucleolus organizer region of Drosophila melanogaster. Proc. Natl. Acad. Sci. U.S.A., 53, 737-745.

ROIHA, H., MILleR, J. R., WoODS, L. C. AND GLOVER, D. M. 1981. Arrangements and rearrangements of sequences flanking the two types of rDNA insertions in Drosophila melanogaster. Nature, 290, 749-753.
ROSENBERG-BOURGIN, M., PAUMARD, S. AND CONTESSE, G. 1988 a. Comparative study of molecular characteristics of $\mathrm{X}$ and $\mathrm{Y}$ nucleolar organizers of various lines of Drosophila melanogaster. Biol. Cell, 62, 201-209.

ROSENBERG-BOURGIN, M., PAUMARD, S., BRACONE, A. AND CONTESSE, G. 1988b. Comparison between the molecular characteristics and the potential activity of $\mathrm{X}$ and $\mathrm{Y}$ nucleolar organizers from various Drosophila melanogaster laboratory lines. Biol. Cell, 64, 3-11.

SPEAR, B. B. 1974. The genes for ribosomal RNA in diploid and polytene chromosomes of Drosophila melanogaster. Chromosoma, 48, 159-179.

TARTOF, K. D. 1973. Unequal sister chromatid exchange and disproportionate replication as mechanisms regulating ribosomal RNA gene redundancy. Cold Spring Harbor Symp. Quant. Biol., 38, 491-500.

TARTOF, K. D. 1974. Unequal mitotic sister chromatid exchange as the mechanism of ribosomal gene magnification. Proc. Natl. Acad. Sci. U.S.A , 71, 1272-1276.

TERRACOL, R. 1987. Differential magnification of rDNA gene types in bobbed mutants of Drosophila melanogaster. Mol. Gen. Genet., 208, 168-176.

TERRACOL, R. AND PRUD'HOMME. N. 1986. Differential elimination of rDNA genes in bobbed mutants of Drosophila melanogaster. Mol. Cell. Biol., 6, 1023-1031.

WAHL, G. M., STERN, M. AND STARK, G. R. 1979. Efficient transfert of large DNA fragments from agarose gels to diazobenzyloxymethyl-paper and rapid hybridization by using dextran sulfate. Proc. Natl. Acad. Sci., 76, 3683-3687.

WELlAUER, P. K., DAWID, I. B. AND TARTOF, K. D. 1978. X and Y chromosomal ribosomal DNA of Drosophila melanogaster: comparison of spacers and insertions. Cell, 14, 269-278. 